the Russia of Stalin and the Russia of Kosygin. The former was contemptuous of public opinion whether domestic or foreign and cared little for popularity and international marks for good conduct. The Russia of today cannot go all the long way back to those dark days.

When one views the injustice and the foolishness of Soviet action in a case such as this, one car gain a greater appreciation for the tradition of dissent that exists in this country. It often seems to be a spindly, harsh and prickly plant, but then it has had to survive some rather bad native weather. In this country dissent has often been-to change the metaphor-a noisy, ineffcient, disorganized process. But it has kept open possibilities of thought and action that would otherwise bave been foreclosed; it has awakened consciences to moral issues that some of us hardly knew existed; it has indicated goals that have passed from utopian dreams, to unlikely possibilities, to practical necessities.

A time of crisis-and Vietnam is surely a crisis for the American people-tests the value of dissent. But it tests equally well those values, attitudes and actions which dissent calls into question. When mere dissent becomes criminal, it is the state that has been convicted.

\section{SOME STARTLING FIGURES}

According to Joseph Alsop, who writes from Washington, "some pretty peculiar reporting from Vietnam plus a lot of flabby thinking in Washington have combined to produce a mood of defeatism in many quarters of this city." As a remedy he recommended looking at the record.

A tabulation of all the reports from the headquarters of General Westmoreland, he said, leads to some startling figures. From January 1 through March 7, according to Alsop's figures, total enemy losses of all kinds must be numbered in the "tens of thousands," enough to allow the judgment that there has been an "astonishing transformation of the war.".

In the New York Times Magazine of March 6, Bemard Fall also did some figuring. With the additional authorization for the current fiscal year "the per capita expenditure for every captured or killed Viet Cong in 1965 will have come to a substantial $\$ 365,111$."

We don't intend to comment. We simply note that the record does provide some rather startling figures.

J. F.

\title{
in the magazines
}

A December Commentary article by Theodore Draper-noted in this column in January-which criticized U.S. policy in the Dominican coup of last April, has stimulated debate in the pages of the National Review, and additional comments by Draper himself have appeared in The New Republic and The New Leader.

In the first of two Nattonal heview articles in the February 8 issue, the editor of Latin American Report, a formet U.S. diplomat in Havana who covered the Dominican crisis, marks the original Draper report "a bitchy, nit-picking performance." This writer, Paul D. Bethel, presents evidence to support the validity of press and official statements about the nature and effects of the Dominican coup which Draper had called into question. And he replies to Draper's assertion that there was little substance to the Johnson Administration's charge of Communist manipulation of the revolt.

Mr. Bethel finds "the scream from the left-Liberal corner over U.S. intervention in the Dominican Republic," both "interesting and significant. Most of Mr. Draper's sources" of information, he says, "are wedded to the proposition that the so-called 'democratic Left' in Latin America is the answer to Communist subversion, and to right-wing pressures." But the very fact of "Communist manipulation of the Dominican revolt," which Bethel is able to establish to his satisfaction, "proves that the 'democratic Left' in that country, at least, is politically ineffective."

"The preponderance of evidence is that Juan Bosch and his Dominican Revolutionary Party [PRD] turned to the Communists, voluntarily; to provide the bone and sinew which the PRD sadly lacked. This truth, for our Liberals, is "unthinkable," Bethel contends. "Therefore the Draper reconstruction."

-

In the second National Review article, J. B. Bender ("pen name of an expert in Latin American affairs"),

2 worldview 